\title{
Strategic Compensation as a Factor of Attraction for Students Graduating in Business Administration: A Brazilian Case
}

\author{
Francisco Junior da Silva Leitão, João Paulo Corrêa Da Silva, Cristina Lourenço Ubeda \\ Department of Business Administration, Federal University of São Carlos (UFSCar), Sorocaba, Brazil \\ Email:francisco.leitao@outlook.com, joao.correa21@yahoo.com.br, cristina-ubeda@ufscar.br
}

Received 19 May 2016; accepted 2 August 2016; published 5 August 2016

Copyright (C) 2016 by authors and Scientific Research Publishing Inc.

This work is licensed under the Creative Commons Attribution International License (CC BY).

http://creativecommons.org/licenses/by/4.0/

c) (i) Open Access

\section{Abstract}

This paper aims to identify the most attractive compensation strategies to students about to complete their undergraduate degree in Business Administration at the Federal University of São Carlos (UFSCar). Thus, it seeks to meet the substantial and growing demand for business management professionals by the productive sectors in the Sorocaba metropolitan area, São Paulo State, Brazil. Strategic compensation systems involve a balanced combination of different forms of compensation in order to achieve three main goals: to attract, retain, and motivate employees, in alignment with organizational goals. In Brazil, this practice was encouraged by the creation of Law No. 10.101 on December 19, 2000, which regulates employees' profit sharing and company performance. The several existing compensation strategies must be tailored within the regional compensation practices, as market practices are parameters for determining the compensation mix in companies. The research method used was a survey to be a procedure for collecting primary data from individuals in line with the descriptive nature of the research. Data were collected through a questionnaire administered to students, using the Likert scale, whose measure was the degree of importance given by respondents to the surveyed items. The scale ranged from 1 to 5 , where 1 was unimportant and 5 was very important. Based on the research population, the results suggest that the most attractive remuneration types are direct salary and benefits, followed by variable compensation and non-financial compensation.

\section{Keywords}

Strategic Compensation, Attractiveness, Rewards 


\section{Introduction}

With the rapid changes in the macroeconomic scenario and increased competitiveness, successful companies that held competitive advantage realized that organizational success lied in the ability to generate results through human capital.

Given this ability, it is possible to identify that companies need to provide a counterpart to its employees. Thus, compensation takes a key role in generating results which goes beyond instrumental and transactional issues of the employment relationship, being a tool that establishes a partnership based on performance [1] [2].

On one hand, the company indicates what its strategic goals are and what is necessary to fulfill them. On the other hand, the employee takes an active role to meet these objectives [3]. Therefore, companies have been seeking alternative compensation systems to leverage results grounded in flexibility, agility and innovation [4]-[6].

The construction of a strategic compensation system begins by breaking the old paradigm and building a new one. New, more flexible strategies for managing people seek to adapt to the needs of the moment. Individuals need to be as flexible as businesses [7].

Lawler (2000) [8] states that the traditional compensation system based on the employee's job and position only makes sense in a world where jobs are designed with previously planned and managed positions. In contexts where creative solutions and more skills and competencies are expected from individuals, a traditional compensation mix can be perceived as unfair by the employee.

The compensation mix involves several types of compensation. However, in order to obtain strategic outcomes, compensation types must be tactically aligned according to their purposes. Attracting, retaining and motivating employees go beyond offering benefits; it requires the right benefits for concrete goals. Although the fundamental choices in determining the compensation strategies may seem clear, practices to develop a global compensation strategy for the work done are very complex [9].

This paper aims to identify the main types of attractive compensation strategies to students about to complete their degrees in Business Administration at the Federal University of São Carlos (UFSCar). It seeks to meet the substantial and growing demand for business management professionals by the productive sectors in the Sorocaba metropolitan area.

It is divided into five sections: the first contains the introduction; the second describes the theoretical research on the theme; the third presents the methodological aspects of the research; the fourth presents the results; and finally, the fifth section presents the final considerations.

\section{Strategic Compensation}

Wood Jr. and Picarelli Filho (2004) [6] state that a strategic compensation system is a balanced combination of different forms of remuneration. Hanashiro, Teixeira and Zaccarelli (2008) [3] corroborate this description when they state that strategic remuneration involves companies making use of the different types of compensation available to compensate their employees for their performance.

Economic and psychological theories claim that compensation strategies must reflect the organization's human resource needs and practices in the job market. They may be grouped into three general categories: attraction, retention and motivation [10].

Thus, the premise of strategic compensation is to create a compensation mix tailored to the organization's business strategy for better business performance [11]. The main difference between the traditional and the strategic compensation approaches lies in the fact that the first compensates the employee for the skills stated in the job description, whereas the second compensates employees for their skill level [5] [12].

Unlike traditional compensation approaches, strategic compensation does not solely involve the necessary labor cost, nor is it usually determined by collective bargaining in the private sector. On the contrary, it is a means to align the unique and inimitable resource of a company-its employees - to the strategic direction of the organization and, in doing so, ensure competitive advantage and create shareholder value [13].

The theory of strategic compensation proposes that activities, attributes and results should support the achievement of organizational goals, thus leading to increased knowledge, skills, flexibility, retention and productivity [9].

Key elements to strategic compensation include wage parity with the market, the use of fixed and variable compensation, short and long-term compensations, and financial and non-financial compensation. Such elements must be organized according to the proportion of eligible work for different forms of compensation [10]. 
In a strategic compensation system, individual financial benefits must be related to the company's payment ability, the definition of organizational goals, and the adoption of performance evaluation systems [14].

In this sense, Trevor (2013) [15] predicts that future organizations will no longer be formally structured, but they will be structured by informal networks, moving from a bureaucratic to a post-bureaucratic organization. Therefore, payment systems shall be as complex and dynamic as these changes, which justify the use of strategic compensation.

A motivating factor for the increased use of strategic compensation in Brazil was the creation of Law no. 10.101 on December 19, 2000, which regulates employees' profit sharing and company performance. Through such law, companies were exempted from paying labor and social security taxes and thus began using preestablished criteria, such as productivity, quality and/or profitability. One of the main advantages of this law was the exemption of labor and social security charges for payments that can be made up to twice a year [16].

Antonietti, Antonioli and Pini (2014) [14] state that variable payment systems such as a profit sharing are generally considered part of the broader set of compensation management practices at the strategic level.

Overall, strategic compensation means compensation practices in alignment with organizational goals in order to attract, retain and motivate employees aiming at improving performance and productivity within the organization. This concept shall be better explained through the models and through the presentation of theme.

\subsection{Models and Application of Strategic Compensation}

Lawler (2000) [8] is one of the first and main theoreticians of strategic compensation. He classifies compensation strategy under three types, presented at Table 1.

This table seeks to show the principles of strategic compensation. The types of compensation must be based on each of the three strategies in order to make the compensation system flexible and adjustable to the goals, behaviors and results expected by the organization. This theory arises at a time when many organizations are moving toward a more diverse and increasingly global workforce, so it is likely that organizations choose to have flexibility - the central idea of strategic compensation—, as companies have traditionally adopted a conventional remuneration approach that is only suited to organizations where work is homogeneous.

Lawler's thought underpins the recent compensation strategic models dealt with in this paper, each with its specific focus. Thus, this study presents four models of strategic compensation: 1) the strategic reward system (SRS), which focuses on stakeholders both in internal and external environments to the organization; 2) the five reward strategies, which focus on the expected impacts of each type of compensation; 3) strategic compensation, which aims at organizing the compensation types according to organizational goals; and 4) Total Reward Strategy, which consists of a holistic compensation model that considers variables such as learning and personal development [8].

The first model, proposed by Hanashiro, Teixeira and Zaccarelli (2008) [3], presents a strategic compensation system that considers the concept of financial and non-financial rewards, and creates value to stakeholders (see Figure 1).

The strategic reward system (SRS) lies in the ability to create value to the four stakeholders-the employee, the organization, the customer and the shareholder-, where the employees are at the core of the system, since they are the ones who will actually be rewarded. The organization, on the other hand, achieves its competitive strategies through different reward modalities, whether financial or non-financial, encouraging specific behaviors by the employees [3].

In this model, the effectiveness of indicators such as productivity, quality and cost reduction coupled with remuneration create favorable conditions for the development of new, more competitive products as well as

Table 1. Compensation strategies.

\begin{tabular}{cl}
\multicolumn{1}{c}{ Strategy } & \multicolumn{1}{c}{ Description } \\
\hline Reward the person & $\begin{array}{l}\text { Reward people for their skills, knowledge and competency based on external } \\
\text { market value. }\end{array}$ \\
Reward for the excellence & $\begin{array}{l}\text { Use variable compensation and stock options to reward their performance. } \\
\text { Meet the characteristics of the individuals the organization intends to attract } \\
\text { and retain. }\end{array}$ \\
\hline
\end{tabular}

Source: Adapted from LAWLER, 2000 [8]. 


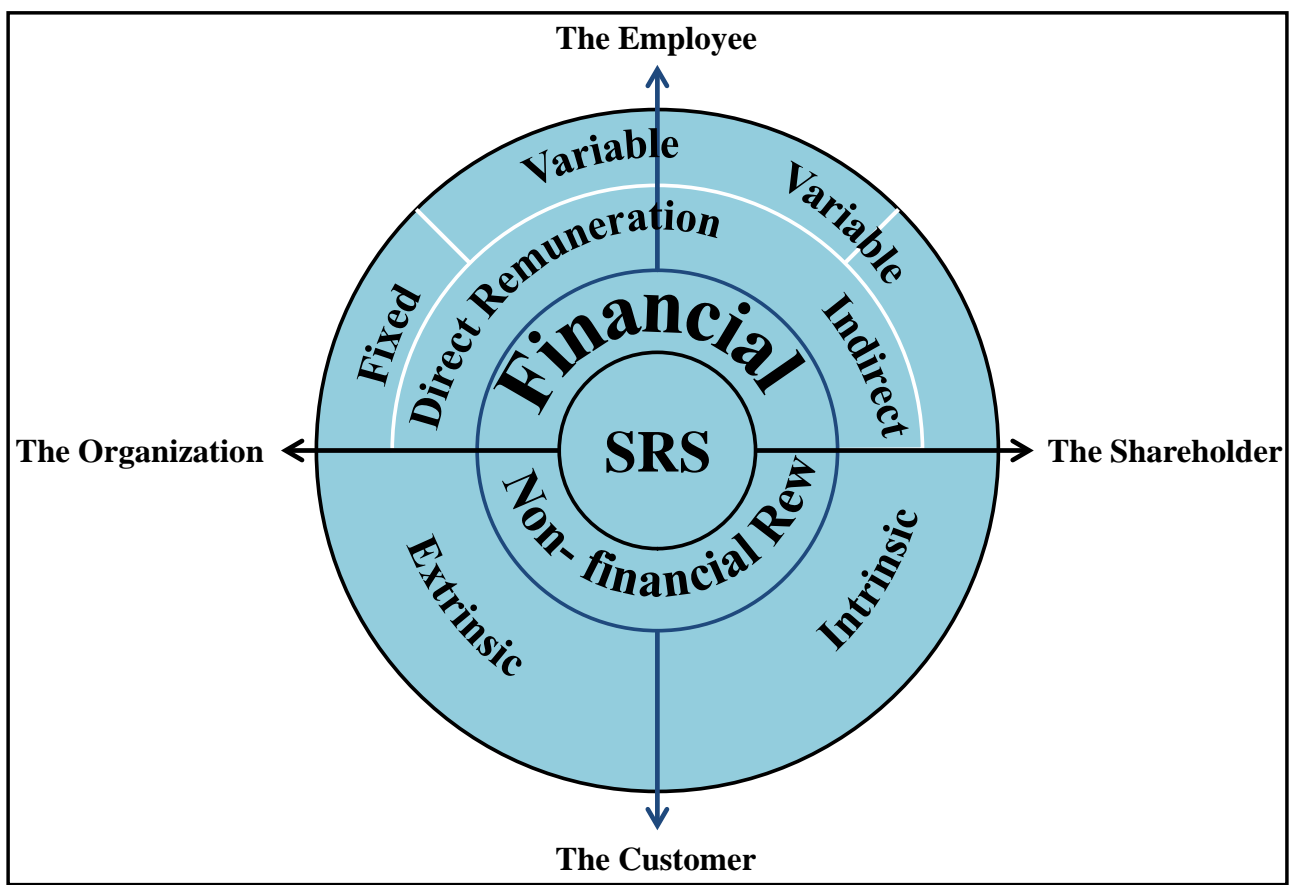

Figure 1. Strategic Reward System (SRS). Source: Adapted from Hanashiro, Teixeira and Zaccarelli (2008) [3].

other compensation strategies such as bonuses granted for exceptional performance.

The second model, proposed by Howards and Dougherty (2004) [9], assumes that compensation only achieves its goal successfully through the recognition of satisfaction and justice by employees, since both factors have a direct impact on people's behaviors. A perceived unfairness by employees may affect their emotional state and have a direct impact on insurance costs, medical expenses and even cause accidents and illnesses.

Within this context, Howards and Dougherty (2004) [9] propose five possible rewards according to the theory of strategic compensation: Individual Output; Group Output; Human Capital; Position, and Market. The strategies and their expected results are compiled in Table 2.

The authors argue that the types of compensation and benefits must be practiced according to the five groups presented. However, this should not be a global strategy within the organization. They make a distinction between two main classes of employees: the managerial class and the operational class. A reward strategy may be considered fair by one class and unfair by the other. The individual effort by a single employee in a production line with interdependent workers, for example, may not change any effort or output and their contributions may be confused up to the final product, so that they are more likely to find individual compensation strategies unfair. In contrast, managers and other independent employees who have greater control over the output of their work may find individual compensation strategies to be fair.

In turn, the third model by Wood Jr. and Picarelli Filho (2004) [6] propose a strategic compensation system based on eight types of compensation: functional compensation; indirect compensation; Pay for skills; Remuneration for competencies; private retirement plans; Variable salary; Shareholding; and creative alternatives. A brief description of each type of compensation is given in Table 3 .

Ideally, this system should present a balance between the 8 types of compensation. Woody Jr. and Picarelli Filho (2004) [6] created a radar chart (polar chart) of compensation. The position of the axes represents the weight of each component relative to the total compensation (the greater the proximity to the outer edge, the greater the importance). Thus, the shape of the inner area represents the profile of the company's compensation system (see Figure 2).

This is the most objective strategic compensation model, as it bring the main types of compensation within a strategic remuneration mix. The applicability of this model depends on the level of importance attributed by the organization to each type of compensation and the expected outcomes in terms of behaviors and results. 
Table 2. Impact of possible reward strategies according to the theory of strategic compensation.

\begin{tabular}{|c|c|c|}
\hline Reward strategy & Description & Strategic impact \\
\hline Individual output & Rewards linked to individual effort, productivity and quality. & Encourage efforts for individual work \\
\hline Group output & Rewards linked to unit or group productivity. & $\begin{array}{l}\text { Encourage teamwork } \\
\text { and collective effort. }\end{array}$ \\
\hline Human capital & Rewards linked to education, skills and competence. & $\begin{array}{c}\text { Encourage skills } \\
\text { development and flexibility. }\end{array}$ \\
\hline Position & Rewards based on work value or on the role of the company & $\begin{array}{l}\text { Encourage the development } \\
\text { of specialized skills }\end{array}$ \\
\hline Market & $\begin{array}{l}\text { Rewards based on salary assessment, } \\
\text { cost of living and market practices. }\end{array}$ & Stimulate labor retention. \\
\hline
\end{tabular}

Source: Compiled from Howard and Dougherty (2004) [9].

Table 3. Types of strategic compensation.

\begin{tabular}{|c|c|}
\hline Type of compensation & Description \\
\hline Functional compensation & $\begin{array}{l}\text { Involves the planning of positions and salaries. It is determined by the employee's role } \\
\text { and adjusted according to the market. }\end{array}$ \\
\hline Indirect salary & Concerns the benefits practiced by the company. \\
\hline Compensation for skills & Is based on skills certified by contributors. \\
\hline Compensation for competencies & Is based on the knowledge, skills and attitudes acquired and performed. \\
\hline Private pension plans & Consist of complements to the pensions. \\
\hline Variable remuneration & Is related to the target achievements of individuals, teams and organizations. \\
\hline Shareholding & Relates to the company’s profitability objectives. \\
\hline Creative alternatives & Include awards and other special forms of recognition. \\
\hline
\end{tabular}

Source: Adapted from Wood Jr.; Picarelli Filho (2004) [6].

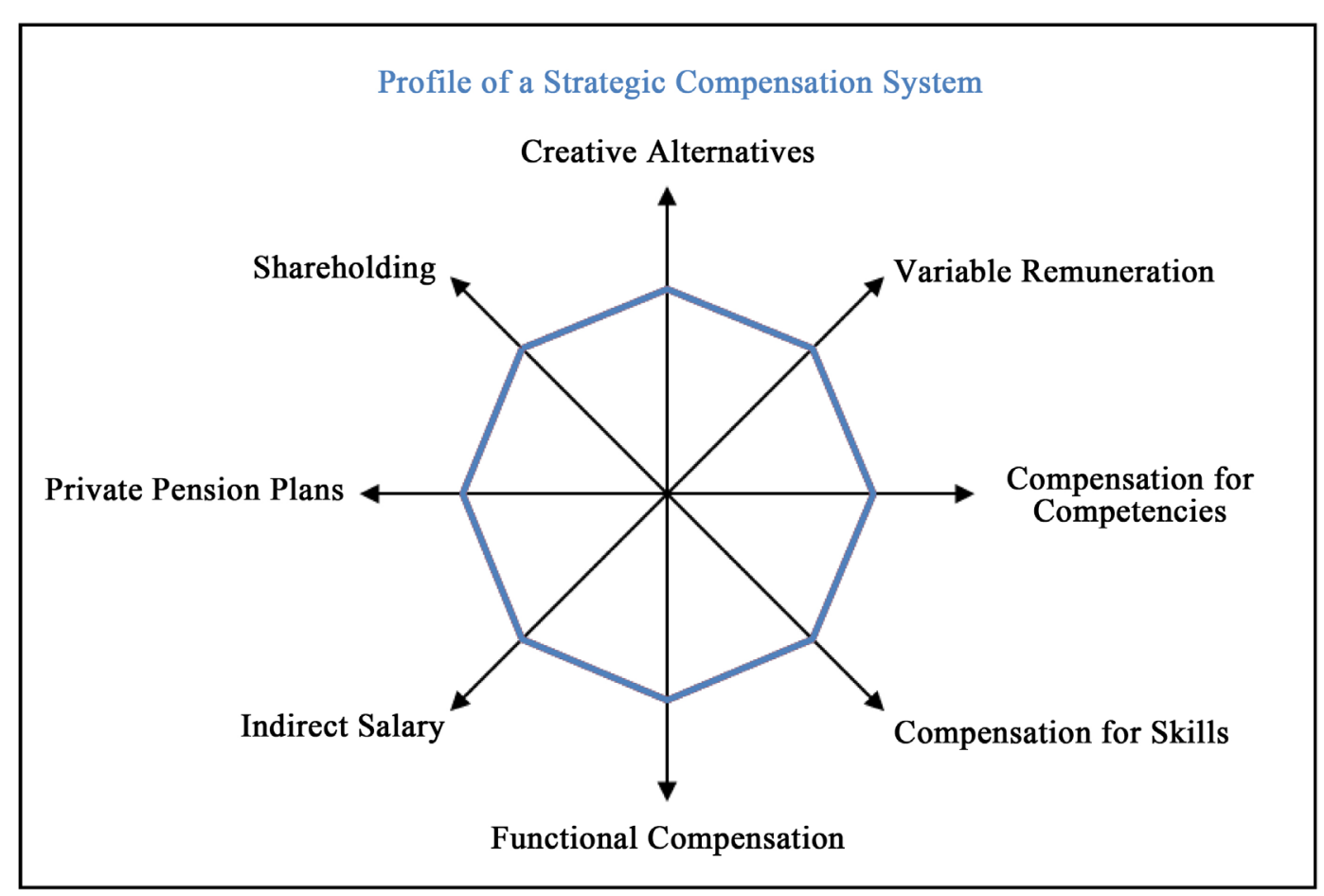

Figure 2. Profile of a strategic compensation system. Source: Wood Jr. and Picarelli Filho (2004) [6]. 
The fourth and final model studied in this article is entitled Total Reward Strategy, a terminology that has been adopted to describe a holistic reward strategy that takes into account additional components to aspects of the work environment, such as learning and development, when creating the benefits package. Its goal is the same as that of strategic compensation, since it involves all the tools available to the employer to attract, motivate and retain employees [9].

Tropman (2001) [17] suggested that the concept of total compensation that he regarded as "New new pay" can be expressed in terms of an equation with ten variables, $\mathrm{TC}=(\mathrm{BP}+\mathrm{AP}+\mathrm{IP})+(\mathrm{WP}+\mathrm{PP})+(\mathrm{OA}+\mathrm{OG})+(\mathrm{PI}+$ $\mathrm{QL})+\mathrm{X}$, where $\mathrm{TC}=$ total compensation; $\mathrm{BP}=$ base salary or wage; $\mathrm{AP}=$ bonuses; $\mathrm{IP}=$ indirect compensation; $\mathrm{WP}=$ equipment used by the employee; $\mathrm{PP}=$ consideration, i.e., special benefits; $\mathrm{OA}=$ opportunity for advancement and greater responsibility; OG = growth opportunity, both through internal and external training; $\mathrm{PI}=$ emotional improvement provided by the work itself and the environment; $\mathrm{QL}=$ quality of life; $\mathrm{X}=$ any element the employee wishes the workplace to facilitate. In practice, this is a very complex model and may require a very detailed cost calculation.

Having presented the models, it is possible to note that the different strategic compensation systems proposed by the authors have converging points; i.e. they are not mutually exclusive, but complementary. It can be said that for a compensation system to be successful, it is necessary to bind compensation to the strategic objectives of the organization as a way to generate better individual results at work and, at the same time, meet employees' expectations regarding financial and non-financial compensation.

As a way to simplify the proposed models, a compilation of such systems was used, giving emphasis on the compensation practices applied at the national level. This is based on the benefits research by Towers Watson consultancy [18] and the types of compensation stated by authors Wood Jr. and Picarelli Filho (2004) [6], Hanashiro, Teixeira and Zaccarelli (2008) [3] and Silva [5].

The simplified compilation was divided into two levels: 1 ) type of compensation in its macro form (direct salary; variable compensation, benefits and non-financial compensation); and 2) compensation practices found in the market, as show in Table 4.

\subsection{Strategic Compensation as a Factor of Attraction, Retention and Motivation}

When the compensation practice aimed at developing organizational skills is linked to compensation according to performance, organizations may use the compensation system as a tool to retain employees [8].

In addition to retention, strategic compensation shows numerous benefits such as strategic alignment, employee satisfaction, salary and performance fairness, and motivation. However, the discussion on multiple compensation strategies leads to the conclusion that compensation systems that seek strategic impact, justice and employee satisfaction have to be complex models and should not be standardized [9].

Two effects are expected on employees who benefit from strategic compensation practices: 1) a positive effect on the motivation of the employees to develop the required skills and competencies, and 2) an increase in the market value of these individuals, which will retain valuable talent in the company [8].

Another advantage is that the increased practice of variable compensation is supposed to be a more appropriate compensation strategy for companies seeking competitive advantage through cost efficiency, as the compensation system helps company control and their labor costs [11].

However, when misdirected, strategic compensation may have the opposite effect. For example, individual compensation for collective performance systems and collective compensation for individual performance systems may sound disconnected, as well as the effects of bonuses and actions in temporal strategies [8].

A disadvantage of the applicability of a strategic compensation system is that, by aligning the thoughts of all employees to the same way of thinking, a variety of answers may arise and this may lead to conflict. Each reward strategy tends to have other non-strategic effects on employees' attitudes and behaviors, which are not always in alignment with the organizational goal [9].

Trevor (2013) [15] points out that, in the long run, strategic compensation may not be enough to achieve organizational goals, as compensation practices tend to be standardized by competition, which results in compensation being aligned with market practices rather than with organizational behaviors.

By exploring the use of effective strategic compensation by leading organizations in Europe, Trevor (2011) [13] found that many organizations experienced profound managerial difficulties when trying to use compensation strategically. When poorly managed, the negative outcomes of strategic compensation systems include high costs, greater administrative burden and labor conflict. 
Table 4. Strategic compensation and compensation practices in Brazil.

\begin{tabular}{|c|c|}
\hline Level 1: Strategic compensation & Level 2: Compensation practices \\
\hline \multirow[t]{3}{*}{ Direct salary } & Functional compensation \\
\hline & Compensation for skills \\
\hline & Compensation for competencies \\
\hline \multirow[t]{4}{*}{ Variable remuneration } & Shareholding \\
\hline & Compensation for performance \\
\hline & Profit sharing \\
\hline & Year-End bonus for results \\
\hline \multirow[t]{21}{*}{ Benefits } & Health insurance plan \\
\hline & Dental plan \\
\hline & Private pension plan \\
\hline & Education aid (for employee) \\
\hline & Education aid (for employee’s children) \\
\hline & Life insurance plan \\
\hline & Outpatient clinic at work \\
\hline & Fuel aid \\
\hline & Chartered transportation \\
\hline & Meals allowance \\
\hline & Paid leave \\
\hline & Legal assistance \\
\hline & Pharmacy benefits \\
\hline & Car parking \\
\hline & Financial loan \\
\hline & Medical check-ups \\
\hline & Employee assistance plan \\
\hline & Fitness centers benefits \\
\hline & Discounted prices at specific stores \\
\hline & Leisure clubs \\
\hline & Childcare \\
\hline
\end{tabular}

Source: Prepared by the authors.

There are many advantages and disadvantages in the application of strategic compensation. The disadvantages lie in the way the system is applied. Therefore, companies must be very clear about the results they expect and the way the system will be applied. Also, the system must the controlled so as to be continuously corrected.

Through a set of 37 questions, a survey by the American consultancy firm Aon Hewitt (2010) [19], which used a sample of 715 employees and took into account company size and profile of the workforce, sought to determine, among other variables, the human capital priority against the focus of organizational strategy by listing the employees' preferences regarding attraction, retention and engagement. As for attraction, the 5 main attributes were: a competitive base salary; competitive health benefits; financial stability of the company; flexible working hours and retirement benefits.

In turn, through a listing of 21 attributes, a Brazilian study published in 2012 by LAB SSJ consultancy in partnership with Clave consulting [20], which used a sample of 10,103 professionals, determined the most im- 
portant attributes in attracting employees based on the value perception people have of the organization and what they value in the categories: rewards, opportunities, organization, people and work. Among what the company has to offer, the attribute with the highest importance was competitive compensation in relation to the market, followed by benefits.

Although the two surveys are not specifically about compensation, their results raise compensation issues studied in this paper. This corroborates the present study, as it focuses on attraction through strategic compensation.

With regard to attraction, retention and motivation, we may conclude that strategic compensation is a powerful tool, as it aims to organize strategic alignment and meet the financial and non-financial expectations by employees and employers.

\section{Methodological Aspects of the Research}

This research can be classified as quantitative and descriptive details as it aims to measure some event or activity, using descriptive statistics. It is a cross-sectional study because the data are collected at a single point in time and summarized statistically [21].

As descriptive study method is used a survey to be a procedure for collecting primary data from individuals. The data may vary between beliefs, opinions, attitudes, experiences and lifestyles [21].

Data collection was carried out through a questionnaire designed using the Likert scale, whose measure was the degree of importance given by respondents to the surveyed items. The scale ranged from 1 to 5 , where 1 was unimportant and 5 was very important.

The questionnaire consisted of objective and closed questions (Appendix). As explained in Table 4 from the types of strategic compensation-direct salary, variable compensation, benefits and non-financial compensation, are considered the main types of remuneration practiced by Brazilian companies based on a research by Towers Watson (2012) [18].

The research population consisted of 52 Business Administration students at UFSCar-Sorocaba Campus-who were about to complete their undergraduate degrees. Out of the participating population who was submitted to the questionnaires, 46 surveys were answered, i.e. approximately $88 \%$ of the population, which can be considered representative.

After the data were collected, the results were calculated by an electronic data editing program and tabulation and a calculation of the measure of central tendency (Median) was used for the analysis of the variables investigated in the research population. The results of the research served as a parameter for the analysis of attraction of graduating students by certain types of compensation and compensation practices as well as for the making of a chart summarizing the tendencies for the main types of compensation mentioned.

\section{Analysis of Results}

This section presents the results of the research. We aimed to identify the main types of attractive remuneration to students graduating in Business Administration at UFSCar in relation to the strategic compensation practices encountered in the market. It is noteworthy that, given the profile of the sample studied, only the impact caused by strategic compensation was considered to attract graduating students.

\subsection{Characteristics of the Brazilian Case}

The Federal University of São Carlos (UFSCar), founded in 1968, is the only federal institution of higher education located in the State of São Paulo/Brazil. It stands out for the high level of qualification of its faculty: 96.1\% of the lecturers hold a doctorate or a master's degree. A majority of lecturers, 98.6\%, carry out teaching, research and extension program activities under a full-time basis [22].

UFSCar has four campuses. The Business Administration undergraduate course is offered in the Sorocaba campus and seeks to meet a substantial and growing demand for business management professionals by the productive sectors in the Sorocaba metropolitan area. The main objective of the course is to provide professionals with a higher education degree in the field of Administration, allowing them to develop conceptual, technical and human competencies, as well as to be able to articulate systematic knowledge and professional action [22].

The investigation conducted in this research involved characteristics of students graduating in Business Administration from UFSCar, at Sorocaba Campus, in relation to strategic compensation as a factor of attraction in organizations. 
The city of Sorocaba is the fourth most populous city in the State of Sao Paulo and the most populous in southern São Paulo state, with a population of 586,625 inhabitants. It is located 100 km from São Paulo city, the most influential Brazilian city on the global stage and is considered the fifth largest city in economic development in the State of São Paulo. Its industrial output reaches more than 120 countries, reaching a GDP of $\mathrm{R} \$ 16.12$ billion. With over 22,000 installed companies—out of which more than two thousand are industriesthe main bases of its economy are the industrial, the commercial and service sectors.

\subsection{Profile of the Surveyed Sample}

Respondents were graduating students in Business administration at the Federal University of São Carlos. The sample was composed of a population of 46 students, $54 \%$ of which were women and the remaining $46 \%$ men. Their maximum age was 30 , where $80 \%$ ranged in age from 18 to 23 years of age and $20 \%$ were between 23 30 . With regard to their insertion in the job market, $41 \%$ were permanent employees, $30 \%$ were trainees, and $28 \%$ were not inserted in the job market up to that moment.

\subsection{Attraction According to Type of Strategic Compensation}

The collected data were the basis for making a radar chart presenting a strategic compensation system, composed by the 4 main types of strategic compensation—Direct Salary; Variable Compensation, Benefits and nonfinancial compensation, analyzed in level 1 . To compose the axes, values 1 to 5 were considered as degrees of importance given by the surveyed population (see Figure 3).

Through this compilation, it is possible to note students' tendency to prefer direct salaries and benefits. However, it is important to highlight that this radar chart may suffer influences over time, stage of life, career or the individual's insertion context or the insertion context of particular groups. Among all kinds of rewards, monetary compensation is always considered one of the most important factors of remuneration; it is not only an encouragement but also a way of retaining employees [23]. Benefits, in turn, are intrinsically and positively linked with the attraction and retention of employees [10], as previously pointed out.

\subsection{Attraction by Type of Compensation: Direct Salary}

Continuing the analyze, in level 2, are considered the main types of remuneration practiced in Brazil. Table 5 presents the ranking with the answers on the type of strategic compensation classified as direct salary and their

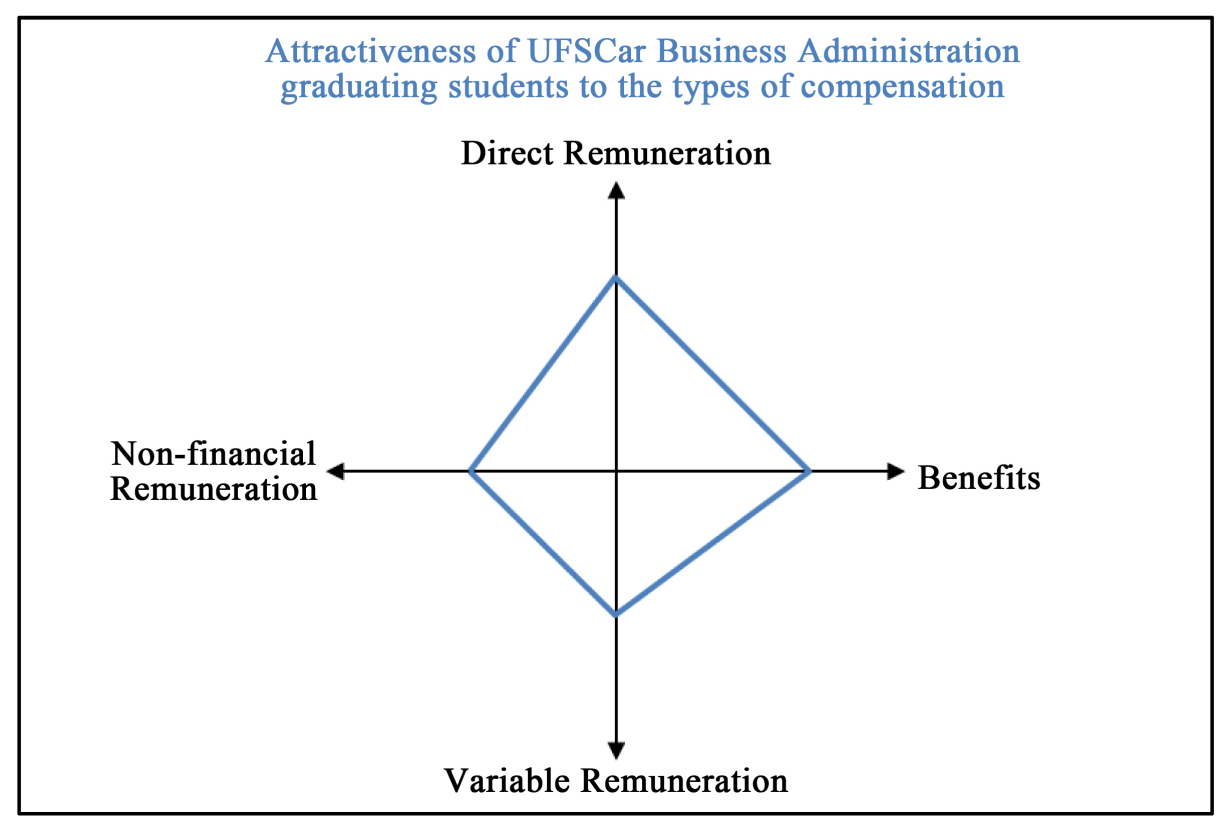

Figure 3. Attractiveness of UFSCar business administration graduating students to the types of strategic compensation. 
Table 5. Ranking: Direct salary and their compensation practices.

\begin{tabular}{|c|c|c|c|c|c|c|c|}
\hline \multirow{2}{*}{ Remuneration: Level 1} & \multirow{2}{*}{ Remuneration: Level 2} & \multicolumn{5}{|c|}{ Importance } & \multirow{2}{*}{ Median } \\
\hline & & 1 & 2 & 3 & 4 & 5 & \\
\hline \multirow[t]{4}{*}{ Direct salary } & & $0 \%$ & $2 \%$ & $2 \%$ & $17 \%$ & $78 \%$ & 5 \\
\hline & Functional compensation & $0 \%$ & $4 \%$ & $11 \%$ & $39 \%$ & $46 \%$ & 4 \\
\hline & Compensation for skills & $0 \%$ & $7 \%$ & $20 \%$ & $37 \%$ & $37 \%$ & 4 \\
\hline & Compensation for competencies & $0 \%$ & $9 \%$ & $26 \%$ & $33 \%$ & $33 \%$ & 4 \\
\hline
\end{tabular}

compensation practices. Answers were calculated based on the Median-measure of central tendency, in addition to frequency percentage.

Direct salary earned top marks among the population surveyed with a median of 5 and a percentile of $78 \%$ on the value 5. Despite receiving the maximum score, the compensation practices showed to be less important in relation to the type. This demonstrates that the students of business administration are more concerned with the market value of their salary than with the form of compensation itself.

In this sense, Gerakos, Ittner and Moers (2013) [10] mention that some companies may offer above average wages in order to generate a sense of satisfaction and assume the worker will be more efficient and feel more valued, thus avoiding the situation where the employee seeks for another job, since other companies will offer a lower compensation for their current post.

\subsection{Attraction According to Type of Compensation: Benefits}

Table 6 shows the ranking with answers on the type of strategic compensation classified as benefits and their compensation practices. Answers were calculated based on the Median-measure of central tendency, in addition to frequency percentage. Benefits received grade 5 among business graduating students. However, the only benefit to reach the highest score was the health insurance plan, with a frequency of $70 \%$.

Benefits have traditionally been seen as a means to attract and retain desired employees, but compensation theories indicate that more than that, they also improve motivation and the productivity of employees [10].

Thus, it is important to recognize that employees value certain benefits but that offering them beyond a certain level will not result in greater satisfaction, performance and higher productivity [3]. The answer some advanced management companies are giving to these issues is the flexibility of benefit plans. Flexible plans give employees the option to choose among available benefits, the ones that best suit their profiles, family situation and lifestyles [6].

\subsection{Attraction According to Type of Compensation: Variable Compensation}

Table 7 presents the ranking with answers on the type of strategic compensation classified as variable compensation and their compensation practices. Answers were calculated by Median-measure of central tendency, in addition to the frequency percentage. Variable remuneration received score 4 through median calculation. On the other hand, their variable short-term compensation practices (compensation by results and profit sharing) received top marks. The long-term compensation practice, however (equity participation), received the lowest score- $41 \%$ gave it value 3 .

This result confirms students' concerns regarding payment based on goals and objectives both collectively (profit sharing) and individually (remuneration for results). On the other hand, there is an explicit preference for short, rather than long-term compensation.

Some forms of payment are based on short-term results (e.g., merit pay and annual bonus), while others are based on long-term outcomes (e.g., stock options and stock option grants).

Thus, compensation criteria that place a greater emphasis on long-term compensation than short-term compensation will motivate behavior and align the interests of employees to achieve long-term performance targets more than short-term performance targets. The concept of temporal orientation is relevant for technology companies since it takes many years for companies to realize the return on their investment in $R \& D$ [11].

The core idea of variable compensation is to share the risks and successes of the business with employees and 
Table 6. Ranking: Benefits and their compensation practices.

\begin{tabular}{|c|c|c|c|c|c|c|c|}
\hline \multirow{2}{*}{$\begin{array}{l}\text { Remuneration: } \\
\text { Level } 1\end{array}$} & \multirow{2}{*}{$\begin{array}{l}\text { Remuneration: } \\
\text { Level } 2\end{array}$} & \multicolumn{5}{|c|}{ Importance } & \multirow{2}{*}{ Median } \\
\hline & & 1 & 2 & 3 & 4 & 5 & \\
\hline \multirow[t]{22}{*}{ Benefits } & & $0 \%$ & $0 \%$ & $15 \%$ & $26 \%$ & $59 \%$ & 5 \\
\hline & Health insurance plan & $0 \%$ & $0 \%$ & $7 \%$ & $24 \%$ & $70 \%$ & 5 \\
\hline & Education aid (for employee) & $0 \%$ & $0 \%$ & $28 \%$ & $41 \%$ & $30 \%$ & 4 \\
\hline & Education aid (for employee’s children) & $4 \%$ & $15 \%$ & $17 \%$ & $39 \%$ & $24 \%$ & 4 \\
\hline & Paid leave & $2 \%$ & $2 \%$ & $11 \%$ & $39 \%$ & $46 \%$ & 4 \\
\hline & Fuel aid & $7 \%$ & $11 \%$ & $20 \%$ & $33 \%$ & $30 \%$ & 4 \\
\hline & Life insurance plan & $2 \%$ & $13 \%$ & $13 \%$ & $30 \%$ & $41 \%$ & 4 \\
\hline & Chartered transportation & $0 \%$ & $13 \%$ & $15 \%$ & $30 \%$ & $41 \%$ & 4 \\
\hline & Meals allowance & $4 \%$ & $11 \%$ & $20 \%$ & $30 \%$ & $35 \%$ & 4 \\
\hline & Dental plan & $2 \%$ & $13 \%$ & $17 \%$ & $28 \%$ & $39 \%$ & 4 \\
\hline & Private pension plan & $9 \%$ & $7 \%$ & $28 \%$ & $28 \%$ & $28 \%$ & 4 \\
\hline & Outpatient clinic at work & $2 \%$ & $7 \%$ & $20 \%$ & $28 \%$ & $43 \%$ & 4 \\
\hline & Legal assistance & $7 \%$ & $20 \%$ & $46 \%$ & $20 \%$ & $9 \%$ & 3 \\
\hline & Employee assistance plan & $0 \%$ & $13 \%$ & $46 \%$ & $15 \%$ & $26 \%$ & 3 \\
\hline & Financial loan & $22 \%$ & $20 \%$ & $37 \%$ & $13 \%$ & $9 \%$ & 3 \\
\hline & Pharmacy benefits & $9 \%$ & $15 \%$ & $35 \%$ & $28 \%$ & $13 \%$ & 3 \\
\hline & Medical check-ups & $0 \%$ & $20 \%$ & $33 \%$ & $28 \%$ & $20 \%$ & 3 \\
\hline & Discounted prices at specific stores & $4 \%$ & $26 \%$ & $46 \%$ & $20 \%$ & $9 \%$ & 3 \\
\hline & Car parking & $9 \%$ & $17 \%$ & $28 \%$ & $26 \%$ & $20 \%$ & 3 \\
\hline & Leisure clubs & $7 \%$ & $24 \%$ & $28 \%$ & $35 \%$ & $7 \%$ & 3 \\
\hline & Childcare & $15 \%$ & $20 \%$ & $28 \%$ & $15 \%$ & $22 \%$ & 3 \\
\hline & Fitness centers benefits & $17 \%$ & $24 \%$ & $24 \%$ & $26 \%$ & $9 \%$ & 3 \\
\hline
\end{tabular}

Table 7. Ranking: variable compensation and compensation practices.

\begin{tabular}{|c|c|c|c|c|c|c|c|}
\hline \multirow{2}{*}{ Remuneration: Level 1} & \multirow{2}{*}{ Remuneration: Level 2} & \multicolumn{5}{|c|}{ Importance } & \multirow{2}{*}{ Median } \\
\hline & & 1 & 2 & 3 & 4 & 5 & \\
\hline \multirow[t]{5}{*}{ Variable remuneration } & & $0 \%$ & $2 \%$ & $26 \%$ & $33 \%$ & $39 \%$ & 4 \\
\hline & Compensation for performance & $0 \%$ & $0 \%$ & $13 \%$ & $24 \%$ & $63 \%$ & 5 \\
\hline & Profit sharing & $0 \%$ & $0 \%$ & $9 \%$ & $33 \%$ & $59 \%$ & 5 \\
\hline & Year-end bonus for results & $0 \%$ & $4 \%$ & $11 \%$ & $41 \%$ & $43 \%$ & 4 \\
\hline & Shareholding & $4 \%$ & $24 \%$ & $41 \%$ & $17 \%$ & $13 \%$ & 3 \\
\hline
\end{tabular}

pay them accordingly [3]. The importance given by the majority of the surveyed population confirms Barret (1991) [24] investigation, who states that people are willing to devote to work and organizational goals and objectives if that brings them a significant return for their efforts and dedication.

\subsection{Attraction According to Type of Compensation: Non-Financial Compensation}

Table 8 presents the ranking with answers on the type of strategic compensation classified as non-financial compensation and their compensation practices. The answers were calculated by Median-measure of central 
Table 8. Ranking: non-financial compensation and compensation practices.

\begin{tabular}{|c|c|c|c|c|c|c|c|}
\hline \multirow{2}{*}{ Remuneration: Level 1} & \multirow{2}{*}{ Remuneration: Level 2} & \multicolumn{5}{|c|}{ Importance } & \multirow[t]{2}{*}{ Median } \\
\hline & & 1 & 2 & 3 & 4 & 5 & \\
\hline \multirow[t]{2}{*}{$\begin{array}{l}\text { Non-financial } \\
\text { remuneration }\end{array}$} & & 11 & $11 \%$ & $24 \%$ & $35 \%$ & $20 \%$ & 4 \\
\hline & Recognition and other non-financial rewards & 11 & $11 \%$ & $24 \%$ & $35 \%$ & $20 \%$ & 4 \\
\hline
\end{tabular}

tendency, in addition to the frequency percentage. Non-financial compensation received score 4 through the median calculation. Since such compensation involves non-standardized alternatives of creative alternatives to generate recognition, the score for the type of compensation was also used for the compensation practices.

It is important to note that, with the modernization of rewards systems, currently the focus lies not only on the employee's pay, but also on the most attractive non-financial benefits in search of motivation management [9].

\section{Final Considerations}

To achieve the aim of identifying the practices and most attractive types of strategic compensations to graduating students from the Business Administration course at UFSCar, this paper highlights the types of compensation and the most common compensation practices. It structures them in a way that allows a systematized and easily accessible reading on the theory of strategic compensation.

The literature shows several compensation mechanisms as independent choices. However, these choices may be complementary or substitutes in the sense that the use of an element increases (or decreases) the advantage of using another element [12].

By choosing compensation practices, companies can influence the attraction and retention of the types of employees that meet their needs and provide incentives to increase their efforts. Thus, it is necessary to know what it aims to attract.

Most studies examine strategic compensation in a general way, but few study all the recurring options in the market including 1) a comparison of salary and benefits with the ones practiced in the market, 2) the use of fixed and variable remuneration and their balance, and 3) what is expected in the short and long terms.

The main type of attractive compensation for students graduating in Business Administration from UFSCar is direct salary, followed by benefits. This fact corroborates empirical studies by Gerakos, Ittner and Moers (2013) [10], who concluded that the practice of above average wages is the greatest instrument of attraction, retention and motivation of staff. Variable compensation is only used to achieve motivational goals, and benefits are used for employee retention. The American consultancy firm Aon Hewitt (2010) [19] determined that the main factor of attraction for American employees is base salary, followed by health benefits. Likewise, the research by the Brazilian consultancy firm LAB SSJ in partnership with Clave Consulting [20], found that the main attributes of attraction a company has to offer are a competitive salary followed by benefits. Therefore, it is possible to notice that both in the Brazilian and in the American contexts, base salary and benefits are the main pillars of attractiveness with respect to compensation.

A limiting factor in this research was the use of a specific population and the lack of comparison with other groups or with the practices of companies in Sorocaba (São Paulo State/Brazil), where the group is inserted.

For future research, we suggest 1) replicating this study on another population to establish a comparative profile with different groups; 2) carrying out a survey of compensation practices in companies in the region in order to confront the practices with the population's expectations; and 3) studying how the adoption of strategic compensation practices impacts on organizations.

\section{References}

[1] Albuquerque, L.G. and Oliveira, P.M. (2001) Competências ou cargos: Uma análise das tendências das bases para o instrumental de recursos humanos. Cadernos de Pesquisas em Administração. http://www.regeusp.com.br/arquivos/v08n4art2.pdf

[2] Andrade, M.T. (1991) O sistema de recompensa na empresa do futuro. Revista de Administração de Empresas, 31, 4953. http://dx.doi.org/10.1590/S0034-75901991000100007 
[3] Hanashiro, D.M.M., Teixeira, M.L.M. and Zaccarelli, L.M. (2008) Recompensando pessoas. In: Hanashiro, et al. (Org.), Gestão do fator humano: Uma visão baseada em stakeholders, Saraiva, São Paulo, 176-215.

[4] Jiang, Z., Xiao, Q., Qi, H. and Xiao, L. (2009) Total Reward Strategy: A Human Resources Management Strategy Going with the Trend of the Times. International Journal of Business and Management, 4, 11. http://dx.doi.org/10.5539/ijbm.v4n11p177

[5] Rodrigues, J.M. (2006) Remuneração e competência: Retórica ou realidade? Revista de Administração de Empresas, 46, 23-34. http://dx.doi.org/10.1590/S0034-75902006000500002

[6] Wood Jr., T. and Picarelli Filho, V. (2004) Remuneração Estratégica: A nova vantagem competitiva. Atlas, São Paulo.

[7] Silva, M.O. (2005) Sistemas modernos de remuneração. Qualitymark, Rio de Janeiro.

[8] Lawler, E.E. (2000) Pay Strategy: New Thinking for the New Millennium. Compensation and Benefits Review, 32, 7-12. http://dx.doi.org/10.1177/088636870003200102

[9] Howards, L.W. and Dougherty, T.W. (2004) Alternative Reward Strategies and Employee Reactions. Compensation and Benefits Review, 42, 179-189. http://dx.doi.org/10.1177/0886368703261273

[10] Gerakos, J., Ittner, C.D. and Moers, F. (2013) Compensation Objectives and Business Unit Pay Strategy. Chicago Booth School of Business Research Paper, No. 08-24.

[11] Yanadori, Y. and Marler, J.H. (2003) Strategic Compensation: Does Business Strategy Influence Compensation in High-Technology Firms? CAHRS Working Paper Series, 26. http://digitalcommons.ilr.cornell.edu/cahrswp/26/

[12] Oliveira, L.M.B. (2001) Estratégias e práticas de remuneração utilizadas pelas empresas brasileiras. Organizações \& Sociedade, 8, 97-108. http://dx.doi.org/10.1590/S1984-92302001000200006

[13] Trevor, J. (2011) Can Pay Be Strategic? A Critical Exploration of Strategic Pay in Practice. Palgrave Macmillan, London. http://ethos.bl.uk/OrderDetails.do?uin=uk.bl.ethos.613360

[14] Antonietti, R., Antonioli, D. and Pini, P. (2014) Flexible Pay Systems and Labour Productivity: Evidence from EmiliaRomagna Manufacturing Firms. University of Ferrara. http://www.siecon.org/online/wp-content/uploads/2014/10/Antonietti-Antonioli-Pini-283.pdf

[15] Trevor, J. (2013) From New Pay to the New, New Pay? World at Work Journal, 19-28. https://www.worldatwork.org/futurereward/journal-article.pdf

[16] Marquart, A., Lunkes, R.J. and Rosa, F.S. (2012) Um estudo sobre práticas de remuneração estratégica nas maiores empresas de Santa Catarina. Gestão e Sociedade, 6, 4-25. http://dx.doi.org/10.21171/ges.v6i13.1289

[17] Tropman, J.E. (2001) The Compensation Solution: How to Develop an Employee-Driven Rewards System. University of Michigan Business School and Management Series. John Wiley and Sons, Hoboken.

[18] Towers Watson (2012) Relatório plano de benefícios no Brasil. Editora 30, São Paulo. http://www.towerswatson.com/pt-BR/Insights/IC-Types/Survey-Research-Results/2014/05/pesquisa-sobre-planos-de-b eneficios-no-brasil

[19] Aon Hewitt (2010) Engagement 2.0: Focus on the Right People. Build the Excitement. Preserve the Passion. http://www.aon.com/attachments/engagement_2\%200_oct2010.pdf

[20] Lab SSJ and Clave Consulting (2012) Atributos da marca empregadora. http://claveconsultoria.com.br/arquivos/LAB ReportEVP.pdf

[21] Hair Jr., J.F., Babin, B., Money, A.H. and Samouel, P. (2008) Essentials of Business Research with SPSS 15. John Wiley \& Sons Canada, Canada.

[22] Ufscar (2016) http://www2.ufscar.br/aufscar/auniversidade.php

[23] Nazir, T., Shah, S.F.H. and Zaman, K. (2012) Literature Review on Total Rewards: An International Perspective. African Journal of Business Management, 6, 3046-3058.

[24] Barret, G.V. (1991) Comparison of Skill-Based Pay with Traditional Job Evaluation Techniques. Human Resources Management Review, 1, 97-105. http://dx.doi.org/10.1016/S1053-4822(05)80002-6 


\section{Appendix: Survey of Strategic Compensation at Work}

Mark an X the answer to classify you:

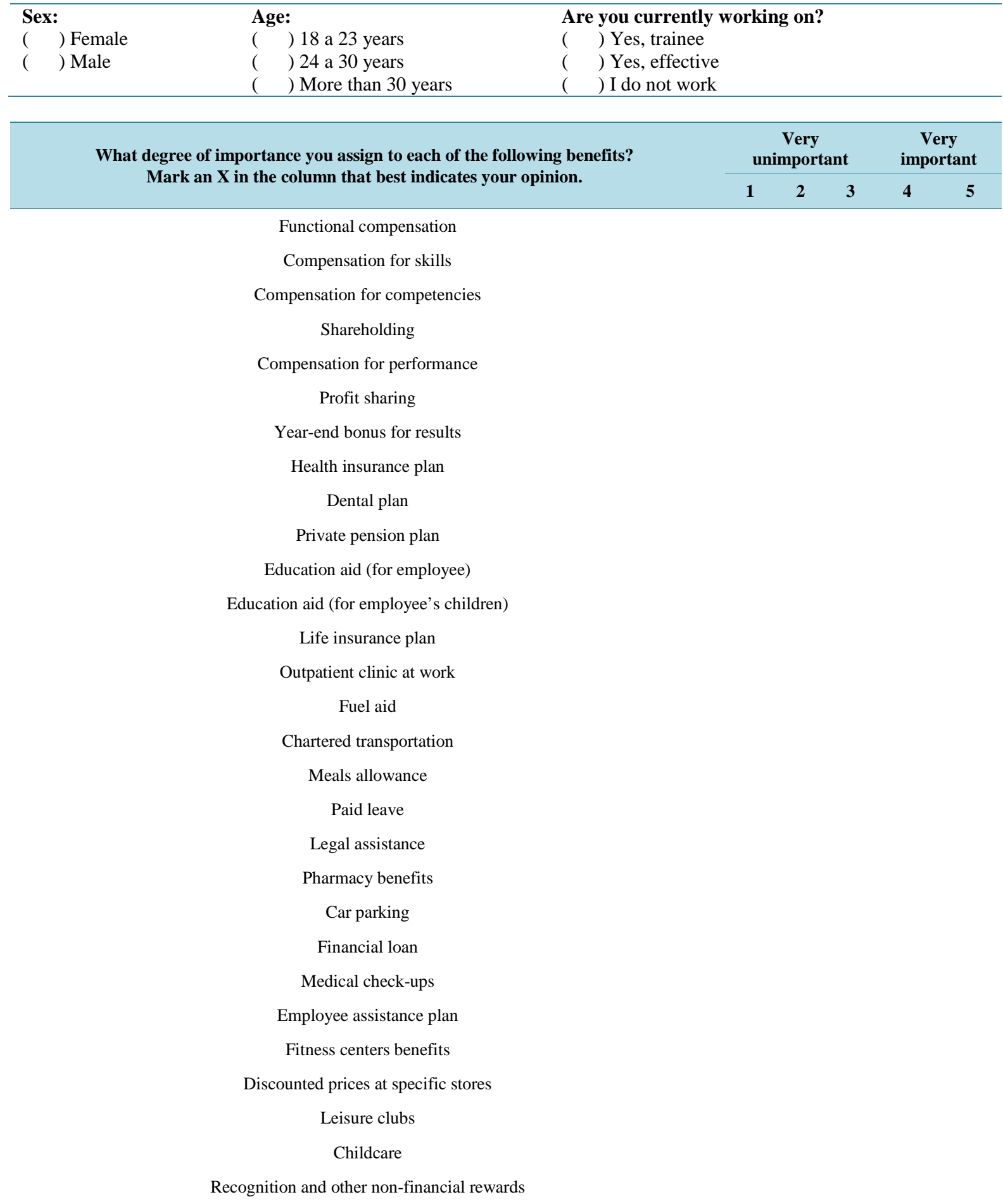




\section{Submit or recommend next manuscript to SCIRP and we will provide best service for you:}

Accepting pre-submission inquiries through Email, Facebook, LinkedIn, Twitter, etc.

A wide selection of journals (inclusive of 9 subjects, more than 200 journals)

Providing 24-hour high-quality service

User-friendly online submission system

Fair and swift peer-review system

Efficient typesetting and proofreading procedure

Display of the result of downloads and visits, as well as the number of cited articles

Maximum dissemination of your research work

Submit your manuscript at: http://papersubmission.scirp.org/ 